Выйти из “бермудского треугольника”: о методологии исследования посткоммунистических трансформаций

\title{
С.М. Елисеев
}

ЕЛИСЕЕВ Сергей Михайлович, доктор политических наук, профессор кафедры теории и философии политики философского факультета Санкт-Петербургского государственного университета.

Посткоммунизм, неожиданно возникнув, образовал своеобразную “научную целину”, которую сразу же принялись осваивать представители самых разных школ и дисциплин. Как заметил К.фон Бойме, “крах реального социализма поставил исследования трансформаций буквально на поток” [Бойме 1994: 148]. Авторы этих исследований, как правило, полагали, что обладают необходимой методологией - достаточно лишь немного “переналадить” уже испытанные мировой наукой инструменты, прежде всего макросоциальные теории и структурно-функциональные подходы. Однако эти инструменты, созданные в условиях “черно-белого” мира и идеологической конфронтации двух систем, оказались мало пригодными для качественного научного анализа переходных процессов периода глобализации, особенно в их начальной фазе. В социальной науке в целом, и прежде всего - в политической, наметился методологический кризис. Можно даже говорить о том, что посткоммунистическое пространство предстало некой “аномальной зоной”, “бермудским треугольником”, где общие законы не действуют или приводят к уникальным, совершенно неожиданным последствиям.

Как же выйти из этого “бермудского треугольника”? Попытаемся сформулировать свое видение проблемы.

\section{Посткоммунистические трансформации как проблема сравнительной политологии}

Предварительно напомним, что существуют два вида теорий: макросоциальные и микросоциальные. Первые строятся на основе объективных долгосрочных структурных факторов и предпосылок общественного развития. Вторые обращаются к краткосрочным факторам развития, уделяя самое пристальное внимание деятельности субъекта.

Макросоциальные теории (речь идет прежде всего о структурно-функциональном анализе, системной теории и марксистской теоретической традиции), несмотря на все существенные различия в их методологии, содержании и понятийном аппарате, роднит признание принципа эмерджентности. Иначе говоря, они исходят из того, что целое больше суммы его частей. Соответственно, общество есть нечто большее, чем сумма отдельных индивидов и их действий. Оно (общество) изменяется по определенным универсальным законам, независимо от этнонациональных, исторических, религиозных, культурных традиций. Последние могут оказывать своеобразное сопротивление общим законам развития, но не способны его остановить. Целью развития является достижение социального прогресса. Под “прогрессом” же чаще всего понимается “направленный процесс, который неуклонно подводит систему все ближе либо к более предпочтительному, лучшему состоянию (или, другими словами, к реализации определенных ценностей этического порядка, таких, например, как счастье, свобода, процветание, справедливость, достоинство, знания и т.д.), либо к идеальному состоянию общества, описанному в многочисленных социальных утопиях. Чаще всего идея прогресса устанавливает, как такое общество должно выглядеть согласно взглядам того или иного автора, его мировоззрению” [Штомпка 1996: 26]. Поэтому содержание “социального прогресса” во многом определяется господствующими идеями и ценностями и может быть весьма разным - от построения социализма и коммунизма до превращения норм западной цивилизации или либеральной демократии в общепланетарные.

Теории, отрицающие эмерджентность, исходят из того, что общество является производным от поведения и действий отдельных людей. Такие теории называют микросоциальными. В социологии к ним относятся, например, теории социального поведения и социального действия, в политологии - теории политической культуры, политического участия и электорального поведения, рационального выбора, политических элит и 
По нашему мнению, к этому типу принадлежат и основные транзитологические концепции. Транзитологическая парадигма возникла на рубеже 1970 - 1980-х годов как своеобразная реакция на господствовавшие ранее в академической среде макросоциальные теории и в связи с необходимостью осмысления особого типа политических процессов перехода от авторитаризма к демократии. Последние отличаются от процессов в стабильно функционирующей системе следующими признаками: усилением социальной напряженности, кризисом легитимности власти, резким падением эффективности политической системы, снижением степени предсказуемости поведения индивидов и групп, ростом потребности в коллективном выходе из кризиса. Сегодня транзитологические исследования стали одним из перспективных направлений в развитии сравнительной политологии [Ильин, Сморгунов 2001: 142]

Исследуя демократизацию (или переходы к демократии) в различных регионах мира, ученые-транзитологи отталкиваются от постулата о том, что процесс зарождения и созревания демократии не обязательно должен быть единообразным и универсальным как в социальном плане, так и по временной протяженности, поскольку поведение и действия политических акторов в такой период в немалой степени обусловлены комбинацией внутренних (эндогенных) и внешних (экзогенных) факторов [Растоу 1996; О’ Доннел 1994]. Другими словами, для каждого этапа демократизации и для каждого региона имеется собственный алгоритм успешного перехода к демократии. Но в алгоритме управления данным переходом выявляются общие корреляционные (положительные и отрицательные) связи, знание которых может быть полезно и с научной, и с практической точки зрения. Транзитологические концепции по своей сути являются теориями среднего уровня, они не претендовали и не претендуют на универсальность.

В начале 1990-х годов, в связи с неспособностью макротеорий дать удовлетворительные объяснения происходящим в мире переменам, прежде всего посткоммунистическим трансформациям, многие ученые стали обращаться к теориям среднего уровня, присваивая им постепенно качества макросоциальности. Это подрывало доверие к транзитологической парадигме, особенно в ее советологической интерпретации. Дело в том, что вместе с крахом “реального социализма” советология утратила свое влияние в политической науке, что подвигло ее представителей к поиску новых теоретических схем. Этот поиск привел их к осознанию необходимости освоения транзитологических теорий, применение которых, однако, часто носило сугубо формальный характер. И хотя многие транзитологи предостерегали против неадаптированного использования транзитологических моделей, созданных на основе обобщения опыта перехода от авторитаризма к демократии в Латинской Америке и Южной Европе, при анализе посткоммунистических трансформаций [Schmitter, Karl 1994], их голос не был услышан. Более того, поскольку представители западной постсоветологии лучше транзитологов знали историю и традиции как СССР, так и стран Восточной Европы, в 1990-е годы они сохранили интеллектуальное лидерство в изучении постсоветских обществ. Но транзитологическая парадигма не сводится к ее советологической интерпретации. Поэтому, по нашему мнению, звучащая у нас в последнее время критика в адрес транзитологии, опирающаяся преимущественно на анализ работ советологов и постсоветологов [см., напр. Капустин 2001], вряд ли справедлива.

Потенциал исследования посткоммунистических трансформаций в рамках сравнительной политологии и транзитологической парадигмы еще далеко не исчерпан [Васович 1998]. Нужно только преодолеть инерцию мышления, отказаться от механического перенесения в XXI в. концептуальных схем, созданных в прошлом, и тогда, сохранив и развив основные принципы транзитологического подхода, обогатив его теоретическими достижениями последних десятилетий, можно будет обобщить эмпирический опыт посткоммунистических изменений.

В этой связи одной из перспективных исследовательских стратегий в рамках сравнительной политологии нам представляется кроссрегиональный анализ процессов посткоммунистических трансформаций (в странах Восточной Европы и России, в России и других государствах СНГ). Известно, что сравнение регионов, т.е. групп стран, избранных в силу схожести их экономических, культурных, политических и иных характеристик, весьма распространено в компаративистике. Исследователи подчеркивают плодотворность подобных подходов, открывающих путь для решения ряда методологических проблем, в частности сравнимости, эквивалентности и т.п. [Сморгунов 1999: 50-51].

Обращение к названным стратегиям позволит быстрее вывести изучение политического развития российского общества на иной уровень, преодолеть своеобразный этноцентризм и наметившееся движение 
теоретической мысли по кругу, “смысловой вакуум” [Ильин 1997: 36], образовавшийся после разрушения прежней социальной реальности.

\section{Неоинституционализм как междисциплинарная парадигма сравнительных исследований}

В настоящее время институциональный подход (в его неоинституциональной ипостаси) вновь стал занимать доминирующие позиции в социальных науках. Нам представляется, что указанная парадигма может быть достаточно эффективной в сравнительных исследованиях, причем не только на монодисциплинарном, но и на междисциплинарном уровне.

Прослеживая эволюцию институционализма на этом последнем уровне, можно отметить, что как особое течение в социальных науках он сложился еще в конце XIX — начале XX в., однако получил в них далеко не одинаковое развитие. Прежде всего указанный подход нашел себе применение в социологической и политической науках. Так, например, Э.Дюркгейм видел в институтах некие идеальные образования в форме обычаев и верований, которые, в свою очередь, материализуются в практической деятельности социальных организаций различных времен и народов [Дюркгейм 1991: 283-284]. По Веберу, институты представляют собой социальные образования, учреждения, сообщества индивидов, которые обладают особыми признаками, а именно: они не зависят от желаний индивида; установлениям, на которые должен ориентироваться в своем поведении индивид, присущ рациональный характер; эти установления включают в себя аппарат принуждения [Вебер 1990: 639-642].

Политическая наука унаследовала традиции институционализма от юриспруденции, в которой понятие “институт” означает совокупность родственных правовых норм, регулирующих определенные общественные отношения. "В самом начале XX столетия, — напоминает С.В.Патрушев, — политическая наука все еще воспринималась как своего рода продолжение немецкого Staatswissenschaft (государствоведения) - изучения государства, его органов и институтов, посредством которых оно осуществляет свои функции” [Патрушев 2001: 150]. Поэтому начальный этап становления политической науки имеет отчетливо выраженный формально-юридический акцент.

И только в экономической науке институционализм долгое время находился на методологической периферии. Объяснение движения хозяйственных благ исключительно институциональными факторами не находило значительного числа сторонников. Отчасти это было связано с неопределенностью самого концепта “институт”: одни исследователи понимали под ним главным образом корпорации, другие профсоюзы, третьи - государство, четвертые - обычаи и т.д., и т. п. Положение осложнялось и тем, что институционалисты пытались использовать в экономике методы других общественных наук — права, социологии, политологии и др. В результате они теряли возможность говорить на едином языке экономической науки, коим считался язык графиков и формул. Были, конечно, и другие объективные причины, по которым данное течение оказалось невостребованным современниками. Однако в $1960-$ 1970-е годы, когда появился “новый институционализм”, ситуация коренным образом изменилась.

Между “старыми” институционалистами (типа Т.Веблена, Дж.Коммонса, Дж.К.Гэлбрейта) и неоинституционалистами (вроде Р.Коуза, Д.Норта или Дж.Бьюкенена) есть принципиальные различия. Во-первых, повторим, “старые” институционалисты шли к экономике от права и политики, пытаясь изучать экономические проблемы методами других наук об обществе; неоинституционалисты же идут прямо противоположным путем - анализируют политологические и правовые проблемы методами неоклассической экономической теории, применяя аппарат современной микроэкономики и теории игр. Во-вторых, традиционный институционализм основывался главным образом на индуктивном методе, стремился идти от частных случаев к обобщениям, вследствие чего общая институциональная теория так и не сложилась; неоинституционализм же ориентируется на дедуктивный метод, продвигаясь от общих принципов неоклассической экономической теории к объяснению конкретных явлений общественной жизни. В-третьих, “старый” институционализм как течение радикальной экономической мысли обращал преимущественное внимание на действия коллективов (в первую очередь профсоюзов и правительства) по защите интересов индивида, тогда как неоинституционализм ставит во главу угла независимого индивида, который по своей воле и в соответствии с собственными интересами решает, членом каких коллективов ему выгоднее выступать.

В политической науке “новый институционализм” появился в середине 1980-х годов, став своеобразной реакцией ученых на преобладание в политических исследованиях бихевиоризма и теории рационального 
выбора и одновременно отражением их стремления продолжить в новых условиях прежние традиции институционализма, опираясь на достижения неоинституционализма в экономической науке и на результаты бихевиористских штудий.

Как известно, современные политологи предлагают далеко не однозначные трактовки понятия “институт”. Например, Д.Норт определяет его как “устанавливаемые людьми ограничения, которые структурируют политическое, экономическое и социальное взаимодействие... неформальные (запреты, табу, обычаи, традиции, кодексы чести и т.д.)... и формальные правила (конституции, законы, права собственности и т.д.), а также систему санкций за их несоблюдение” [Норт 1997: 17]. А.Степан видит в институте правила принятия решений и системы стимулов; С.Кроуфорд и Э.Остром - правила, нормы и совместные стратегии; П.Холл - формальные правила, процедуры достижения согласия и стандартно действующие практики, структурирующие отношения между индивидами; Г.О’ Доннелл — “коллективное действие по управлению, либерализации (liberation) и расширению поля индивидуальных действий” или “упорядочивающие образцы взаимодействия” [цит. по: Патрушев 2001: 154]. Несмотря на различия в определениях, представители неоинституциональной школы едины в том, что институты есть набор формальных правил, неформальных ограничений и механизмов их принудительного осуществления.

Другими словами, институты - это согласованные правила игры в обществе. Они создают структуру побудительных мотивов человеческого поведения, уменьшают неопределенность, организуя повседневную жизнь. Основная функция институтов - обеспечить стабильность через сглаживание изменений в соотношении цен. Институциональная стабильность делает возможным сложный обмен политической деятельностью и ее результатами. Но здесь важно подчеркнуть: сама по себе стабильность отнюдь не означает, что институты функционируют эффективно. Будучи необходимым условием сложного взаимодействия между политическими акторами, она не тождественна эффективности. Последнюю, согласно неоинституциональному подходу, обеспечивают такие факторы, как конкуренция, децентрализация принятия решений, правила и нормы, устраивающие не только выигрывающие, но и проигрывающие в тот или иной момент организации. Безусловно эффективны те правила, которые блокируют неудачные действия и поддерживают удачные. Именно они инициируют рост экономического и общественного капитала [Норт 1997].

Источником институциональных изменений в политике (как и в экономике) является эволюция мировосприятия людей, которая отражается в сдвигах в их отношении к ценностям и/или в изменении порядка ценностных предпочтений. Важно то, что формальные правила могут быть одномоментно заменены государством, а неформальные ограничения эволюционируют очень медленно. И формальные правила, и неформальные ограничения в конечном счете складываются под воздействием субъективного мировосприятия людей, которое, в свою очередь, и определяет эксплицитный выбор формальных правил и развитие неформальных ограничений. Институты отличаются от организаций. Институты суть правила игры, а организации - это группы индивидов, которых связывает общая целевая функция.

В данном контексте хотелось бы специально отметить принципиальную возможность использования некоторых достижений экономического неоинституционализма в исследованиях посткоммунистических трансформаций. Например, модель Д.Норта, объясняющую, почему силы конкуренции далеко не всегда ведут к “отбраковке” неэффективных “правил игры” и почему застойные формы экономики способны существовать тысячелетиями, можно применить при компаративном анализе процессов институционализации политических партий и партийных систем в странах демократического транзита (в частности, при сравнении протекания такого рода процессов в странах Центральной Европы и в России или в СНГ).

Норт обращает внимание на то, что высокие трансакционные издержки делают политический рынок мало похожим на совершенный рынок неоклассической теории. В связи с этим ученый выделяет следующие главные факторы, препятствующие “отбраковке” неэффективных “правил игры” в политике: (а) в их сохранении бывает заинтересовано государство (если они способствует максимизации разницы между доходами и расходами казны); (б) их могут поддерживать могущественные группы со специальными интересами; (в) эволюция общества зависит от однажды избранной институциональной траектории (раth dependence): новые, более эффективные “правила игры” нередко остаются незадействованными потому, что их введение требует значительных первоначальных вложений, в которых не нуждаются уже давно укоренившиеся институты. 
Все это, по мнению Норта, стабилизирует сложившуюся институциональную систему, независимо от степени ее эффективности. Институты как бы “заталкивают” общество в определенную колею, из которой потом трудно выбраться. В любом обществе, указывает он, всегда образуется “смесь” из эффективных и неэффективных институтов, и именно соотношение между ними определяет в конечном счете траекторию социального развития.

Попробуем применить предложенный Нортом метод к анализу эффективности партий и партийных систем в странах демократического транзита (и переходной экономики). При таком подходе сразу же становится очевидным, что низкую эффективность партий и партийной системы в России (по сравнению, например, со странами Центральной Европы) можно объяснить не только с помощью сугубо политологической аргументации (например, электоральной культурой).

Если подойти к проблеме с позиций неоинституционализма и определить государство (прежде всего в лице государственной бюрократии) как заинтересованного игрока на политическом рынке, то можно сделать следующий вывод: частые изменения “правил игры” (в частности, создание нестабильной избирательной и партийной систем, постоянное внесение изменений в институт избирательного права, его корректировки в ходе самого электорального процесса) могут быть интерпретированы двояко - либо как следствие неадекватного использования государством общественного капитала, что ведет к спонтанному складыванию или воссозданию неформальных институтов, препятствующих демократизации (традиции, обычая, привычки к правовой нестабильности), либо как результат прямой заинтересованности государственной бюрократии в сохранении своего доминирующего положения на политическом рынке. Говоря словами Норта, неустойчивость “правил игры” способствует максимизации разницы между доходами и расходами казны и поддерживается могущественными группами со специальными интересами.

Представляет несомненный интерес и теория “эксплуататорского государства”, согласно которой государство, используя монополию на насилие, пытается максимизировать собственные доходы и/или доходы группы, обладающей наибольшим потенциалом насилия и контролирующей государственный аппарат в ущерб благосостоянию общества. Главная цель указанной группы — создание и поддержание такой структуры собственности, которая позволяет максимизировать ее доходы. Именно в этом и кроется причина систематических “набегов” государственного аппарата во все сферы взаимодействия людей, в т.ч. и политическую. Поэтому в появлении феномена “партии власти”, имеющего сугубо российскую специфику и не наблюдаемого в странах Восточной Европы, можно видеть реализацию стратегии “эксплуататорского государства”, стремящегося сохранить свое доминирующее положение на политическом рынке [Голосов, Лихтенштейн 2001; Рябов 1998].

Политическая активность бюрократии наиболее значительна как раз в переходные для демократии периоды, когда идет быстрое формирование государственных институтов. Понятную озабоченность приверженцев неоинституционализма (например, представителя вирджинской школы П.Бернхольца) вызывает то, что чрезмерная интервенция бюрократии в политический процесс приводит к дисбалансу общественных интересов в результате искажения воли избирателей, а следовательно - к нарастанию в обществе антидемократических тенденций [Макарычев 1995]. При этом бюрократия выражает не только собственный интерес, но и интересы ряда клиентел и лоббистских групп, что еще сильнее искажает картину на политическом рынке.

Таким образом, дополнительным фактором искажения предпочтений избирателей выступают собственные запросы и “аппетиты” исполнительной власти, влияние которых ощущается не только на этапе конституирования представительных органов, но и на этапе исполнения законодательных решений. Избиратели формируют законодательные органы, эти органы комплектуют бюрократию, а та осуществляет управление избирателями. В итоге избиратели, голосовавшие за депутатов, оказываются в непосредственном подчинении у бюрократов.

\section{Институциональная эффективность и легитимность избирательных и партийных систем}

Тезис о том, что характер избирательной системы оказывает решающее воздействие на структуру межпартийной конкуренции, общепринят и вряд ли нуждается в дополнительном обосновании. Менее проработана проблема эффективности и легитимности выбора институциональных условий политической деятельности, иными словами, вопросы о том, какими именно интересами, предпочтениями, ценностями руководствуются игроки, устанавливая те или иные формальные и неформальные “правила игры”, какой 
“политический доход” они надеются получить в случае введения новых институциональных ограничений, упорядочивающих взаимодействия на политическом поле.

На нормативном уровне институционализация и легитимация политической деятельности в ходе посткоммунистических трансформаций призваны создать стабильно функционирующую, эффективную демократическую систему, т.е. обеспечить рост экономического, политического и общественного капитала. Этим задачам подчинены процедуры выбора институциональных условий политической деятельности. Однако не все участники процесса выработки новых “правил игры” имеют одинаковые “политический вес” и предпочтения. Поэтому всегда есть риск принятия согласованных, но стратегически неэффективных решений, ограничивающих доступ каких-то игроков к стратегическим ресурсам власти. В этом случае могут быть достигнуты отдельные тактические цели, но отнюдь не цель стратегическая - создание устойчивой демократической системы.

Институциональная эффективность избирательной и партийной систем в условиях демократии определяется, на наш взгляд, их способностью блокировать неудачные и поддерживать удачные коллективные действия, укрепляющие конкурентную среду и гарантирующие ротацию политических сил у власти в установленном законом порядке, без потрясений и сбоев. Априори невозможно определить, будут ли предлагаемые системы действенными или нет. Необходимо время для их проверки как на эффективность, так и на легитимность. Процесс легитимации избирательной и партийной систем есть часть общего процесса легитимации власти. Необходимость такой легитимации была заложена в самом кризисе авторитарного режима, преодоление которого и является одной из задач демократизации.

\section{Этапы легитимации избирательных и партийных систем}

В свое время нам уже приходилось писать о нормативной структуре легитимации власти, о своеобразном алгоритме такой легитимации [Ачкасов и др. 1996: 47-58]. Напомним, что данный алгоритм включает в себя:

— выработку и институционализацию избирательных правил и норм политической деятельности на основе минимального консенсуса между ведущими группами интересов;

- убежденность ключевых политических акторов в справедливости принятых правил и норм и готовность действовать в соответствии с ними; иными словами, веру в то, что указанные нормы и правила образуют эффективный демократический механизм смены правящих групп путем честной политической борьбы (плюрализм и политическая конкуренция);

— соблюдение политическими акторами принятых правил и норм.

Теперь рассмотрим с позиций неоинституционализма процесс легитимации избирательной и партийной систем. Первый и самый важный этап этого процесса — выбор и принятие правил и норм избирательной и партийной систем. Именно на данном этапе создаются условия и предпосылки достижения институциональной стабильности и эффективности указанных систем и предупреждения их попятного движения.

Неоинституционализм исходит из предположения о том, что система законов (независимо от степени их формализации) представляет собой общественный капитал, отдача от которого меняется с течением времени. Поведение политических акторов может либо укреплять этот капитал, либо уменьшать его (при отказе от соблюдения установленных законом требований); либо размывать основы политической структуры, либо поддерживать их. Все зависит от того, какая линия поведения будет казаться акторам наиболее рациональной.

С точки зрения теории игр, принятие основными политическими акторами общенациональных “правил игры” может происходить по принципам:

(a) игры “с нулевой суммой”, когда в результате взаимодействия объем материальных благ остается неизменным, но победитель (“сильный игрок”) получает все. На практике это означает, что один из участников создания “правил игры”, занимая господствующие позиции на стадии их разработки, диктует “слабым игрокам” свою волю и сознательно заставляет их принять выгодные ему нормы, дабы сохранить свое доминирование и существенно ограничить властные возможности других политических акторов; 
(б) игры с “ненулевой суммой”, когда в результате взаимодействия меняется совокупный объем благ, а выигрыш и проигрыш каждого игрока приблизительно равновероятны. Это возможно, если ни один из участников создания “правил игры” объективно не имеет доминирующего положения либо если существующие институты ограничивают — в интересах достижения более высоких, стратегических интересов (например, установления общенационального согласия) - попытки игроков воспользоваться своими временными преимуществами.

Поскольку демократия предполагает определенность процедур и неопределенность результата (в отличие от авторитарного режима с его неопределенностью процедур и определенностью результата), можно сделать следующий вывод: выбор первого варианта в условиях демократического транзита означает, по сути, продолжение прежней авторитарной традиции, носителем которой становится тот политический актор, который инициирует принятие данного варианта и настаивает на его институционализации. Результатом, скорее всего, окажется рост институциональной нестабильности в связи с обострением борьбы между основными политическими акторами. Ущемленные участники политического процесса будут стремиться внести изменения в установленные “правила игры”, скорректировать их в сторону большей справедливости, а доминирующий актор - сопротивляться такого рода изменениям и маневрировать с целью создать видимость прогресса перед лицом общественного мнения. То, что изменения рано или поздно придется принять, совершенно бесспорно, ибо большинство политических акторов, даже соглашаясь следовать существующим правилам и нормам, не будут убеждены в их справедливости и, соответственно, станут делегитимировать их своими действиями. Но если на уровне политической элиты не удается достичь консенсуса относительно правил легитимации избирательной и партийной систем, то эти системы лишаются доверия и со стороны звеньев гражданского общества и отдельных граждан. В итоге будет возрастать число избирателей, не принимающих участия в выборах или систематически голосующих “против всех”.

Таким образом, только второй вариант открывает возможность достижения институциональной стабильности и эффективности избирательной и партийной систем, поскольку строится на демократической традиции и порождает веру в справедливость и законность принятых правил и норм легитимации законодательной и исполнительной власти, а также создает необходимые институциональные условия укоренения консолидированной демократии.

\section{Противоречия между технологией создания и целями политических организаций}

Теории неоинституционализма содержат еще одну интересную формулу: “зависимость от выбранной траектории” или “зависимость от выбранного маршрута”. Эта формула первоначально была призвана объяснить то, как специфическое технологическое развитие определяло затем выбор конкретной технологии. Здесь же, вслед за Нортом, мы используем данное положение для описания одной из ключевых характеристик институционального устройства, связанной с тем, что институты формируют институциональный выбор и тем самым усложняют изменение управления политическими процессами после принятия того или иного маршрута. Дело в том, что политические партии и группы интересов - лишь следствие институционально ограниченных возможностей, которые диктуются непосредственно существующей институциональной структурой.

В постсоветской России разработка избирательного законодательства и выбор электоральной системы в 1993 г. были во многом обусловлены сложившейся в тот момент социально-политической ситуацией. Пришедшие к власти политические силы имели серьезные основания опасаться того, что они не получат необходимой поддержки на выборах, и Государственная Дума попадет под контроль КПРФ. Как писал в свое время М.Дюверже, “партии всегда развиты больше слева, чем справа, потому что там они всегда более необходимы” [Дюверже 2002: 513]. Левые в лице КПРФ несомненно превосходили тогда правых по уровню организованности, дисциплины, развития партийной инфраструктуры. Поэтому выбор смешанной модели избирательной системы был продиктован не столько стремлением власти создать условия для победы правых партий и становления стабильной и эффективной многопартийной системы, сколько желанием максимально ограничить влияние КПРФ в Госдуме. В этом плане можно констатировать, что тактическая задача волновала разработчиков электорального законодательства и создателей избирательной системы гораздо больше стратегической. Конечно, как отмечал еще Дюверже, ликвидация политических партий была бы замечательным средством парализовать левую оппозицию [Дюверже 2002: 513], но построение современной демократии невозможно без участия политических партий, без развитой многопартийности. Последующее выборы в Госдуму показали, что предложенная модель избирательной системы не позволяет решить ни одну из поставленных задач: ни обеспечить победу правых на выборах, ни создать стабильную, 
эффективную, авторитетную многопартийную систему. Вместо этого она способствовала консолидации национальной и региональной бюрократии, объединению различных ее фракций в движения и появлению все новых версий так наз. “партии власти”.

\section{Партии, институционализация партийной системы и консолидации демократии}

Как показывает мировая практика, достижение стабильной демократии и консолидации общества обеспечивают массовые и “всеохватывающие” партии, но никогда — партии “картельного типа”. Здесь уместно вспомнить об опыте стран Южной Европы, осуществивших переход к демократии в $1970-1980$-е годы_1_, а также о процессах, происходивших в Центральной Европе в конце прошлого столетия [см. Голосов 1998; Рихард, Внук-Липиньский 2002]. Рассмотрим эти процессы на примере Польши.

Начало институционализации и легитимации избирательной и партийной систем в Польше положили “круглый стол” весной 1989 г. и организованные летом того же года учредительные выборы. Основные “правила игры” были, таким образом, установлены, хотя исполнялись они еще непоследовательно. В следующие два-три года ситуация улучшилась. Реальные доказательства эффективности институционального выбора были получены уже в 1993 г., когда оппозиция взяла власть, а силы, правившие до тех пор, стали оппозицией. Это был первый сигнал о том, что ведущие политические акторы приняли новые “правила игры”, как бы те ни сказывались на них в тактическом плане. “Солидарность” уступила власть посткоммунистическим силам, признав результаты выборов справедливыми.

Вторым ключевым моментом в институционализации и легитимации системы был 1997 г., когда по результатам выборов посткоммунистические силы передали власть “Электоральной акции Солидарность” (ЭАС) и Союзу Свободы. “В это время, — пишут А.Рихард и Э.Внук-Липиньский, — не было сколько-нибудь заметной политической силы, которая бы оспорила программно демократическую процедуру легитимации режима. Такая сила не появилась потому, что для ее создания не было социальной базы. На этом основании можно сделать вывод, что примерно к 1997 г. демократическая процедура стала единственно стабильным и значимым путем легитимации режима или, используя термин Де Пальмы, популяризированный Линцем и Степаном, демократические правила стали “единственной игрой в городе” [Рихард, Внук-Липиньский 2002: 67]. Признание всеми участниками политического процесса справедливости и эффективности существующей избирательной системы привело к консолидации в Польше партийной системы. По истечению первого десятилетия посткоммунистических трансформаций не только в Польше, но и в ряде других государств Центральной Европы утвердилось “неоспоримое господство демократических процедур легитимации режима” (согласно критериям, предложенным Х.Линцем и А.Степаном) [Linz, Stepan 1996].

В случае с Россией налицо попытки легитимировать институциональную нестабильность и осуществить переход к демократии с помощью политических образований, объединяющих несколько клиентел и мало пригодных для развертывания политической деятельности в период становления демократии и гражданского общества. Большинство упомянутых образований напоминают партии картельного типа, среди которых выделяется одна, обладающая исключительными ресурсами (административными, финансовыми, информационными). Она и “назначается” (номинируется) правящей.

Смысл возникновения партий картельного типа в условиях стабильной и консолидированной демократии состоит, как известно, в том, чтобы выработать механизм распределения государственных постов между группами профессиональных политиков, основывающийся на непосредственной связи между лидерами и избирателями, сокращении дистанции между ними и предполагающий широкое использование коалиционных принципов [см., напр. Сморгунов 1999: 194]. Попытки создания аналогичных конструкций в России преследуют несколько иную цель: смонтировать механизм распределения государственных постов между группами административно-политической и экономической элиты, минимально зависящий от воли избирателей. Ни о каком сокращении дистанции между политиками и избирателями, государством и гражданским обществом в принципе не идет и речи. Но партии картельного типа не могут консолидировать демократию, поскольку они сами есть продукт ее эволюционного развития.

При неконсолидированной демократии такие партии являются дополнительным источником политической и социальной нестабильности. Они не столько интегрируют социально-экономическое и политическое пространство, сколько создают видимость интеграции; не столько способствуют росту демократической легитимности, сколько порождают тенденцию к делегитимации всего политического режима, ибо своими 
действиями формируют в обществе и внутри политического класса убеждение во временности имеющихся институтов и норм. Отсюда - линия на внесение все новых и новых поправок в избирательное законодательство от имени или по инициативе доминирующих акторов, введение дополнительных ограничений для “слабых” игроков с целью снизить риск поражения на выборах и, соответственно, уменьшения своих “политических прибылей”_2_. Тем самым доминирующие акторы повышают вероятность собственной электоральной победы, но одновременно дестабилизируют существующую институциональную систему коллективного действия по управлению и по легитимации власти.

Институционализация отношений внутри партии картельного типа (между различными группами административно-политической и экономической элиты) носит, как свидетельствует опыт России, временный характер. Различия интересов этих групп неизбежно ведут к нарушениям картельных соглашений, к борьбе между различными фракциями элиты, а также к постоянному изменению финансовых, гражданских и избирательных норм, направленному на достижение относительного преимущества одной фракции над другими.

Как известно, разрозненные “институциональные процессы могут продолжать сосуществовать друг с другом без всеохватывающей интеграции” [Бергер, Лукман 1995: 136]. Именно это мы наблюдаем сегодня в России, именно это не позволяет ее избирательной и партийной системам достичь институциональной стабильности и, следовательно, быть признанными в обществе в качестве легитимных. “Легитимация создает новые значения, служащие для интеграции тех значений, которые уже свойственны различным институциональным процессам. Функция легитимации заключается в том, чтобы сделать объективно доступными и субъективно вероятными уже институционализированные объективации” [Бергер, Лукман 1995: 151].

Все более очевидно, что принятие закона РФ “О политических партиях” — наряду с образованием федеральных округов, реорганизацией Совета Федерации, приведением регионального законодательства в соответствие с федеральным, перераспределением бюджета между федеральным центром и регионами полностью вписывается в логику административной реформы. Ее осуществление отдано в руки бюрократии, которая не заинтересована в контроле за собой со стороны каких-либо структур, разве что самого Президента и его окружения. Административно-правовой код создания большинства политических партий, выигрывавших парламентские выборы в России, не вызывает сомнений. В рамках созданного здесь политического пространства с помощью современных административных ресурсов и политтехнологий конструируются партии (или партия), ориентированные на максимизацию собственной прибыли в результате победы на очередных парламентских выборах. Говоря словами Ж.Бодрийяра, “цель не полагается в итоге, а наличествует изначально, зафиксированная в коде” [Бодрийяр 2000: 129]. Такой порядок действия делает нецелесообразным, с точки зрения бюрократии, развитие институтов гражданского общества. Подобного рода партии выражают интересы скорее государства (точнее, его бюрократического аппарата), нежели гражданского общества. Бюрократия федерального и регионального уровней, освободившись в 1991 г. от политического контроля со стороны номенклатуры КПСС, не горит желанием вновь становиться под контроль какой-либо политической организации, представляющий интересы общества и неподконтрольной ей самой. Используя терминологию Бодрийяра, можно сказать, что как правящим, так и оппозиционным политическим партиям отводится место “симулякра” политического участия.

Именно в связи с этим партии и партийная система в целом в России не легитимируются. Они отвергаются обществом по причине их искусственного происхождения. Непартийные институты гражданского общества (общественные движения, некоммерческие организации, ассоциации малого и среднего бизнеса и т.д.), осуществляющие самостоятельную, независимую от государства деятельность, не признают в большинстве политических партий равноправных партнеров, видя в них прежде всего институты, управляемые государством и нередко лишь симулирующие политическую активность. Поэтому политические партии, особенно возникшие в посткоммунистический период, не имеют прочной социальной базы и вынуждены постоянно маневрировать и мимикрировать, ища поддержки у самых различных групп населения.

\section{Пиар-компании и политические партии}

Анализируя процессы, происходящие в посткоммунистическом мире, с позиций неоинституциональной теории, нельзя обойти молчанием активность еще одного игрока на политическом поле. Речь идет о профессиональных пиар-компаниях. Они также обладают своим интересом, который не без успеха отстаивают как на институциональном, так и на внеинституциональном уровне. 
Существующие в России электоральные и партийные институты поддерживают рынок пиар-технологий, который по разным оценкам составляет около 1 млрд. долл. Слабость политических партий, их организационная и идейная рыхлость открывают перед пиар-компаниями довольно широкую перспективу. Основные политические партии (включая “партию власти”) являются для политтехнологов своеобразными “заготовками” для грядущих избирательных кампаний_3_.

Сохранение нынешнего состояния избирательных институтов и норм выгодно и этому специфическому игроку на политическом поле России. Он тоже стремится максимизировать собственную прибыль, совершенствуя электоральные технологии, заблаговременно готовясь к новым избирательным кампаниям. Для него создание системы сильных гражданских партий означало бы потерю значительной части рынка. Очевидно, что пиар-компании могут быть заинтересованы в создании и функционировании только партий картельного типа, деятельность которых предполагает активное использование политтехнологий и не требует ни развития гражданского общества, ни массового усвоения норм гражданской политической культуры, ни повышения уровня политического участия населения.

$* * *$

В заключение хотелось бы сказать, что сравнительный анализ посткоммунистических трансформаций в принципе можно осуществлять как на макро-, так и на микросоциальном уровне. Более того, чем раньше состояние переходности уйдет в историю, тем скорее будут востребованы макросоциальные подходы. Но в настоящий период эффективнее теории среднего уровня. Неоинституциональная парадигма в сочетании с транзитологией дает в руки исследователя довольно надежный инструмент сравнительного анализа трансформационных процессов, протекающих в постсоциалистическом пространстве.

Ачкасов В.А., Елисеев С.М., Ланцов С.А. 1996. Легитимация власти в постсоциалистическом российском обществе. М.

Бергер П., Лукман Т. 1995. Социальное конструирование реальности. М.

Бодрийяр Ж. 2000. Символический обмен и смерть. М.

Бойме К., фон. 1994. Теория трансформации - новая междисциплинарная отрасль знания? - Государство и право, № 7.

Васович В. 1998. Переход к демократии в посткоммунистических странах (парадоксы перехода-демократизации). - Вестник МГУ, сер. 18, № 2.

Вебер М. 1990. Основные социологические понятия. — Избранные произведения. М.

Голосов Г. 1998. Партийные системы России и стран Восточной Европы. М.

Голосов Г.В., Лихтенштейн А.В. 2001. “Партии власти” и российский институциональный дизайн: теоретический анализ - Полис, № 1.

Дюверже М. 2000. Политические партии. М.

Дюркгейм Э. 1991. О разделении общественного труда. Метод социологии. М.

Закатова А. 2002. Партийная система еще не работает. Если КПРФ и “Единой России” нужно будущее, им нужно измениться. - Независимая газета, 17.04.

Ильин М.В. 1997. Слова и смыслы: опыт описания ключевых политических понятий. М.

Ильин М.В., Сморгунов Л.В. 2001. Сравнительная политология. - Политическая наука, № 2.

Капустин Б. 2001. Конец “транзитологии”? (О теоретическом осмыслении первого посткоммунистического десятилетия). — Полис № 4.

Макарычев А.С. 1995 Принципы и параметры общественного выбора (исследования вирджинской школы). 
— Полис, № 4.

Норт Д. 1997. Институты, институциональные изменения и функционирование экономики. М.

О’ Доннел Г. 1994. Делегативная демократия. - Пределы власти, № 2-3.

Патрушев С.В. 2001. Институционализм в политической науке: Этапы, течения, идеи, проблемы. Политическая наука, № 2.

Растоу Д. 1996. Переходы к демократии: попытка динамической модели. — Полис, № 5.

Рихард А., Внук-Липиньский Э. 2002. Источники политической стабильности и нестабильности в Польше. - Социологические исследования, № 6.

Рябов, А. 1998. “Партия власти” в политической системе современной России. — Макфол М., Марков С., Рябов А. (ред.). Формирование партийно-политической системы в России. М.

Сморгунов Л.В. 1999. Сравнительная политология. Теория и методология измерения демократии. СПб.

Штомпка П. 1996. Социология социальных изменений. М.

Linz J.J., Stepan A. 1996. Problems of Democratic Transition and Consolidation. Southern Europe, South America, and Post-Communist Europe. Baltimore, L.

Schmitter Ph. C., Karl T.L. 1994. The Conceptual Travels of Transitologists and Consolidologists: How Far to the East Should They Attempt to Go? — Slavic Review, vol. 53, № 1.

1 В Греции созданное А.Папандреу еще в 1974 г. социалистическое движение ПАСОК сумело не только осуществить переход к демократии, но и сохранить власть в своих руках вплоть до настоящего времени. (Правда, в 1989 - 1993 гг. правительство формировала правоцентристская “Новая демократия”.) В Испании в ноябре 1975 г., после смерти Франко и воцарения Хуана Карлоса были легализованы ряд политических партий и профсоюзы. В декабре 1978 г. вступила в силу новая конституция, а спустя четыре года, в 1982 г., к власти пришло правительство, сформированное Испанской социалистической рабочей партией, под руководством которой, собственно говоря, и были сделаны основные шаги по созданию демократической политической системы.

2 В этот контекст прекрасно вписывается недавняя инициатива центристов, предложивших поднять избирательный порог для партий, претендующих на место в Государственной Думе.

3_ Как выразился глава “Фонда эффективной политики” Г.Павловский, “между выборами наши партии представляют собой сырье для будущих избирательных проектов”. То есть партии суть “полуфабрикаты”, а выборы - “конкурсы искусств электоральных проектов” [цит. по Закатова 2002]. 


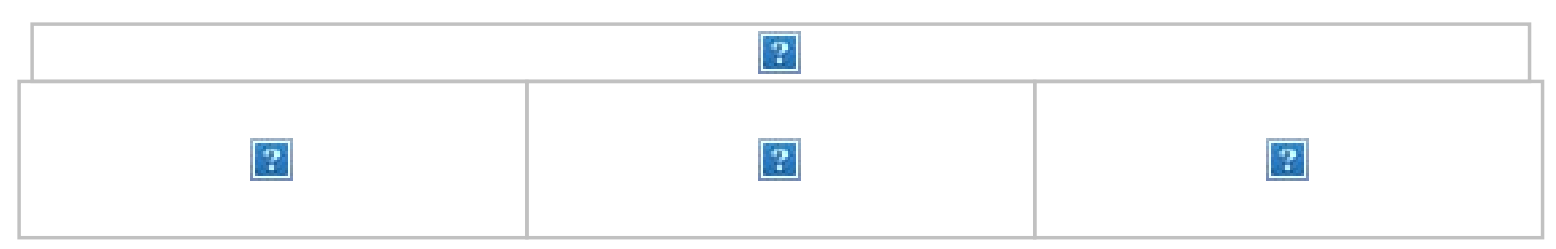

Выйти из “бермудского треугольника”: о методологии исследования посткоммунистических трансформаций

\section{С.М. Елисеев}

ЕЛИСЕЕВ Сергей Михайлович, доктор политических наук, профессор кафедры теории и философии политики философского факультета Санкт-Петербургского государственного университета.

Посткоммунизм, неожиданно возникнув, образовал своеобразную “научную целину”, которую сразу же принялись осваивать представители самых разных школ и дисциплин. Как заметил К.фон Бойме, “крах реального социализма поставил исследования трансформаций буквально на поток” [Бойме 1994: 148]. Авторы этих исследований, как правило, полагали, что обладают необходимой методологией - достаточно лишь немного “переналадить” уже испытанные мировой наукой инструменты, прежде всего макросоциальные теории и структурно-функциональные подходы. Однако эти инструменты, созданные в условиях “черно-белого” мира и идеологической конфронтации двух систем, оказались мало пригодными для качественного научного анализа переходных процессов периода глобализации, особенно в их начальной фазе. В социальной науке в целом, и прежде всего - в политической, наметился методологический кризис. Можно даже говорить о том, что посткоммунистическое пространство предстало некой “аномальной зоной”, “бермудским треугольником”, где общие законы не действуют или приводят к уникальным, совершенно неожиданным последствиям.

Как же выйти из этого “бермудского треугольника”? Попытаемся сформулировать свое видение проблемы.

\section{Посткоммунистические трансформации как проблема сравнительной политологии}

Предварительно напомним, что существуют два вида теорий: макросоциальные и микросоциальные. Первые строятся на основе объективных долгосрочных структурных факторов и предпосылок общественного развития. Вторые обращаются к краткосрочным факторам развития, уделяя самое пристальное внимание деятельности субъекта.

Макросоциальные теории (речь идет прежде всего о структурно-функциональном анализе, системной теории и марксистской теоретической традиции), несмотря на все существенные различия в их методологии, содержании и понятийном аппарате, роднит признание принципа эмерджентности. Иначе говоря, они исходят из того, что целое больше суммы его частей. Соответственно, общество есть нечто большее, чем сумма отдельных индивидов и их действий. Оно (общество) изменяется по определенным универсальным законам, независимо от этнонациональных, исторических, религиозных, культурных традиций. Последние могут оказывать своеобразное сопротивление общим законам развития, но не способны его остановить. Целью развития является достижение социального прогресса. Под “прогрессом” же чаще всего понимается “направленный процесс, который неуклонно подводит систему все ближе либо к более предпочтительному, лучшему состоянию (или, другими словами, к реализации определенных ценностей этического порядка, таких, например, как счастье, свобода, процветание, справедливость, достоинство, знания и т.д.), либо к идеальному состоянию общества, описанному в многочисленных социальных утопиях. Чаще всего идея прогресса устанавливает, как такое общество должно выглядеть согласно взглядам того или иного автора, его мировоззрению” [Штомпка 1996: 26]. Поэтому содержание “социального прогресса” во многом определяется господствующими идеями и ценностями и может быть весьма разным - от построения социализма и коммунизма до превращения норм западной цивилизации или либеральной демократии в общепланетарные.

Теории, отрицающие эмерджентность, исходят из того, что общество является производным от поведения и действий отдельных людей. Такие теории называют микросоциальными. В социологии к ним относятся, например, теории социального поведения и социального действия, в политологии - теории политической культуры, политического участия и электорального поведения, рационального выбора, политических элит и 
По нашему мнению, к этому типу принадлежат и основные транзитологические концепции. Транзитологическая парадигма возникла на рубеже 1970 - 1980-х годов как своеобразная реакция на господствовавшие ранее в академической среде макросоциальные теории и в связи с необходимостью осмысления особого типа политических процессов перехода от авторитаризма к демократии. Последние отличаются от процессов в стабильно функционирующей системе следующими признаками: усилением социальной напряженности, кризисом легитимности власти, резким падением эффективности политической системы, снижением степени предсказуемости поведения индивидов и групп, ростом потребности в коллективном выходе из кризиса. Сегодня транзитологические исследования стали одним из перспективных направлений в развитии сравнительной политологии [Ильин, Сморгунов 2001: 142]

Исследуя демократизацию (или переходы к демократии) в различных регионах мира, ученые-транзитологи отталкиваются от постулата о том, что процесс зарождения и созревания демократии не обязательно должен быть единообразным и универсальным как в социальном плане, так и по временной протяженности, поскольку поведение и действия политических акторов в такой период в немалой степени обусловлены комбинацией внутренних (эндогенных) и внешних (экзогенных) факторов [Растоу 1996; О’ Доннел 1994]. Другими словами, для каждого этапа демократизации и для каждого региона имеется собственный алгоритм успешного перехода к демократии. Но в алгоритме управления данным переходом выявляются общие корреляционные (положительные и отрицательные) связи, знание которых может быть полезно и с научной, и с практической точки зрения. Транзитологические концепции по своей сути являются теориями среднего уровня, они не претендовали и не претендуют на универсальность.

В начале 1990-х годов, в связи с неспособностью макротеорий дать удовлетворительные объяснения происходящим в мире переменам, прежде всего посткоммунистическим трансформациям, многие ученые стали обращаться к теориям среднего уровня, присваивая им постепенно качества макросоциальности. Это подрывало доверие к транзитологической парадигме, особенно в ее советологической интерпретации. Дело в том, что вместе с крахом “реального социализма” советология утратила свое влияние в политической науке, что подвигло ее представителей к поиску новых теоретических схем. Этот поиск привел их к осознанию необходимости освоения транзитологических теорий, применение которых, однако, часто носило сугубо формальный характер. И хотя многие транзитологи предостерегали против неадаптированного использования транзитологических моделей, созданных на основе обобщения опыта перехода от авторитаризма к демократии в Латинской Америке и Южной Европе, при анализе посткоммунистических трансформаций [Schmitter, Karl 1994], их голос не был услышан. Более того, поскольку представители западной постсоветологии лучше транзитологов знали историю и традиции как СССР, так и стран Восточной Европы, в 1990-е годы они сохранили интеллектуальное лидерство в изучении постсоветских обществ. Но транзитологическая парадигма не сводится к ее советологической интерпретации. Поэтому, по нашему мнению, звучащая у нас в последнее время критика в адрес транзитологии, опирающаяся преимущественно на анализ работ советологов и постсоветологов [см., напр. Капустин 2001], вряд ли справедлива.

Потенциал исследования посткоммунистических трансформаций в рамках сравнительной политологии и транзитологической парадигмы еще далеко не исчерпан [Васович 1998]. Нужно только преодолеть инерцию мышления, отказаться от механического перенесения в XXI в. концептуальных схем, созданных в прошлом, и тогда, сохранив и развив основные принципы транзитологического подхода, обогатив его теоретическими достижениями последних десятилетий, можно будет обобщить эмпирический опыт посткоммунистических изменений.

В этой связи одной из перспективных исследовательских стратегий в рамках сравнительной политологии нам представляется кроссрегиональный анализ процессов посткоммунистических трансформаций (в странах Восточной Европы и России, в России и других государствах СНГ). Известно, что сравнение регионов, т.е. групп стран, избранных в силу схожести их экономических, культурных, политических и иных характеристик, весьма распространено в компаративистике. Исследователи подчеркивают плодотворность подобных подходов, открывающих путь для решения ряда методологических проблем, в частности сравнимости, эквивалентности и т.п. [Сморгунов 1999: 50-51].

Обращение к названным стратегиям позволит быстрее вывести изучение политического развития российского общества на иной уровень, преодолеть своеобразный этноцентризм и наметившееся движение 
теоретической мысли по кругу, “смысловой вакуум” [Ильин 1997: 36], образовавшийся после разрушения прежней социальной реальности.

\section{Неоинституционализм как междисциплинарная парадигма сравнительных исследований}

В настоящее время институциональный подход (в его неоинституциональной ипостаси) вновь стал занимать доминирующие позиции в социальных науках. Нам представляется, что указанная парадигма может быть достаточно эффективной в сравнительных исследованиях, причем не только на монодисциплинарном, но и на междисциплинарном уровне.

Прослеживая эволюцию институционализма на этом последнем уровне, можно отметить, что как особое течение в социальных науках он сложился еще в конце XIX — начале XX в., однако получил в них далеко не одинаковое развитие. Прежде всего указанный подход нашел себе применение в социологической и политической науках. Так, например, Э.Дюркгейм видел в институтах некие идеальные образования в форме обычаев и верований, которые, в свою очередь, материализуются в практической деятельности социальных организаций различных времен и народов [Дюркгейм 1991: 283-284]. По Веберу, институты представляют собой социальные образования, учреждения, сообщества индивидов, которые обладают особыми признаками, а именно: они не зависят от желаний индивида; установлениям, на которые должен ориентироваться в своем поведении индивид, присущ рациональный характер; эти установления включают в себя аппарат принуждения [Вебер 1990: 639-642].

Политическая наука унаследовала традиции институционализма от юриспруденции, в которой понятие “институт” означает совокупность родственных правовых норм, регулирующих определенные общественные отношения. "В самом начале XX столетия, — напоминает С.В.Патрушев, — политическая наука все еще воспринималась как своего рода продолжение немецкого Staatswissenschaft (государствоведения) - изучения государства, его органов и институтов, посредством которых оно осуществляет свои функции” [Патрушев 2001: 150]. Поэтому начальный этап становления политической науки имеет отчетливо выраженный формально-юридический акцент.

И только в экономической науке институционализм долгое время находился на методологической периферии. Объяснение движения хозяйственных благ исключительно институциональными факторами не находило значительного числа сторонников. Отчасти это было связано с неопределенностью самого концепта “институт”: одни исследователи понимали под ним главным образом корпорации, другие профсоюзы, третьи - государство, четвертые - обычаи и т.д., и т. п. Положение осложнялось и тем, что институционалисты пытались использовать в экономике методы других общественных наук — права, социологии, политологии и др. В результате они теряли возможность говорить на едином языке экономической науки, коим считался язык графиков и формул. Были, конечно, и другие объективные причины, по которым данное течение оказалось невостребованным современниками. Однако в $1960-$ 1970-е годы, когда появился “новый институционализм”, ситуация коренным образом изменилась.

Между “старыми” институционалистами (типа Т.Веблена, Дж.Коммонса, Дж.К.Гэлбрейта) и неоинституционалистами (вроде Р.Коуза, Д.Норта или Дж.Бьюкенена) есть принципиальные различия. Во-первых, повторим, “старые” институционалисты шли к экономике от права и политики, пытаясь изучать экономические проблемы методами других наук об обществе; неоинституционалисты же идут прямо противоположным путем - анализируют политологические и правовые проблемы методами неоклассической экономической теории, применяя аппарат современной микроэкономики и теории игр. Во-вторых, традиционный институционализм основывался главным образом на индуктивном методе, стремился идти от частных случаев к обобщениям, вследствие чего общая институциональная теория так и не сложилась; неоинституционализм же ориентируется на дедуктивный метод, продвигаясь от общих принципов неоклассической экономической теории к объяснению конкретных явлений общественной жизни. В-третьих, “старый” институционализм как течение радикальной экономической мысли обращал преимущественное внимание на действия коллективов (в первую очередь профсоюзов и правительства) по защите интересов индивида, тогда как неоинституционализм ставит во главу угла независимого индивида, который по своей воле и в соответствии с собственными интересами решает, членом каких коллективов ему выгоднее выступать.

В политической науке “новый институционализм” появился в середине 1980-х годов, став своеобразной реакцией ученых на преобладание в политических исследованиях бихевиоризма и теории рационального 
выбора и одновременно отражением их стремления продолжить в новых условиях прежние традиции институционализма, опираясь на достижения неоинституционализма в экономической науке и на результаты бихевиористских штудий.

Как известно, современные политологи предлагают далеко не однозначные трактовки понятия “институт”. Например, Д.Норт определяет его как “устанавливаемые людьми ограничения, которые структурируют политическое, экономическое и социальное взаимодействие... неформальные (запреты, табу, обычаи, традиции, кодексы чести и т.д.)... и формальные правила (конституции, законы, права собственности и т.д.), а также систему санкций за их несоблюдение” [Норт 1997: 17]. А.Степан видит в институте правила принятия решений и системы стимулов; С.Кроуфорд и Э.Остром - правила, нормы и совместные стратегии; П.Холл - формальные правила, процедуры достижения согласия и стандартно действующие практики, структурирующие отношения между индивидами; Г.О’ Доннелл — “коллективное действие по управлению, либерализации (liberation) и расширению поля индивидуальных действий” или “упорядочивающие образцы взаимодействия” [цит. по: Патрушев 2001: 154]. Несмотря на различия в определениях, представители неоинституциональной школы едины в том, что институты есть набор формальных правил, неформальных ограничений и механизмов их принудительного осуществления.

Другими словами, институты - это согласованные правила игры в обществе. Они создают структуру побудительных мотивов человеческого поведения, уменьшают неопределенность, организуя повседневную жизнь. Основная функция институтов - обеспечить стабильность через сглаживание изменений в соотношении цен. Институциональная стабильность делает возможным сложный обмен политической деятельностью и ее результатами. Но здесь важно подчеркнуть: сама по себе стабильность отнюдь не означает, что институты функционируют эффективно. Будучи необходимым условием сложного взаимодействия между политическими акторами, она не тождественна эффективности. Последнюю, согласно неоинституциональному подходу, обеспечивают такие факторы, как конкуренция, децентрализация принятия решений, правила и нормы, устраивающие не только выигрывающие, но и проигрывающие в тот или иной момент организации. Безусловно эффективны те правила, которые блокируют неудачные действия и поддерживают удачные. Именно они инициируют рост экономического и общественного капитала [Норт 1997].

Источником институциональных изменений в политике (как и в экономике) является эволюция мировосприятия людей, которая отражается в сдвигах в их отношении к ценностям и/или в изменении порядка ценностных предпочтений. Важно то, что формальные правила могут быть одномоментно заменены государством, а неформальные ограничения эволюционируют очень медленно. И формальные правила, и неформальные ограничения в конечном счете складываются под воздействием субъективного мировосприятия людей, которое, в свою очередь, и определяет эксплицитный выбор формальных правил и развитие неформальных ограничений. Институты отличаются от организаций. Институты суть правила игры, а организации - это группы индивидов, которых связывает общая целевая функция.

В данном контексте хотелось бы специально отметить принципиальную возможность использования некоторых достижений экономического неоинституционализма в исследованиях посткоммунистических трансформаций. Например, модель Д.Норта, объясняющую, почему силы конкуренции далеко не всегда ведут к “отбраковке” неэффективных “правил игры” и почему застойные формы экономики способны существовать тысячелетиями, можно применить при компаративном анализе процессов институционализации политических партий и партийных систем в странах демократического транзита (в частности, при сравнении протекания такого рода процессов в странах Центральной Европы и в России или в СНГ).

Норт обращает внимание на то, что высокие трансакционные издержки делают политический рынок мало похожим на совершенный рынок неоклассической теории. В связи с этим ученый выделяет следующие главные факторы, препятствующие “отбраковке” неэффективных “правил игры” в политике: (а) в их сохранении бывает заинтересовано государство (если они способствует максимизации разницы между доходами и расходами казны); (б) их могут поддерживать могущественные группы со специальными интересами; (в) эволюция общества зависит от однажды избранной институциональной траектории (раth dependence): новые, более эффективные “правила игры” нередко остаются незадействованными потому, что их введение требует значительных первоначальных вложений, в которых не нуждаются уже давно укоренившиеся институты. 
Все это, по мнению Норта, стабилизирует сложившуюся институциональную систему, независимо от степени ее эффективности. Институты как бы “заталкивают” общество в определенную колею, из которой потом трудно выбраться. В любом обществе, указывает он, всегда образуется “смесь” из эффективных и неэффективных институтов, и именно соотношение между ними определяет в конечном счете траекторию социального развития.

Попробуем применить предложенный Нортом метод к анализу эффективности партий и партийных систем в странах демократического транзита (и переходной экономики). При таком подходе сразу же становится очевидным, что низкую эффективность партий и партийной системы в России (по сравнению, например, со странами Центральной Европы) можно объяснить не только с помощью сугубо политологической аргументации (например, электоральной культурой).

Если подойти к проблеме с позиций неоинституционализма и определить государство (прежде всего в лице государственной бюрократии) как заинтересованного игрока на политическом рынке, то можно сделать следующий вывод: частые изменения “правил игры” (в частности, создание нестабильной избирательной и партийной систем, постоянное внесение изменений в институт избирательного права, его корректировки в ходе самого электорального процесса) могут быть интерпретированы двояко - либо как следствие неадекватного использования государством общественного капитала, что ведет к спонтанному складыванию или воссозданию неформальных институтов, препятствующих демократизации (традиции, обычая, привычки к правовой нестабильности), либо как результат прямой заинтересованности государственной бюрократии в сохранении своего доминирующего положения на политическом рынке. Говоря словами Норта, неустойчивость “правил игры” способствует максимизации разницы между доходами и расходами казны и поддерживается могущественными группами со специальными интересами.

Представляет несомненный интерес и теория “эксплуататорского государства”, согласно которой государство, используя монополию на насилие, пытается максимизировать собственные доходы и/или доходы группы, обладающей наибольшим потенциалом насилия и контролирующей государственный аппарат в ущерб благосостоянию общества. Главная цель указанной группы — создание и поддержание такой структуры собственности, которая позволяет максимизировать ее доходы. Именно в этом и кроется причина систематических “набегов” государственного аппарата во все сферы взаимодействия людей, в т.ч. и политическую. Поэтому в появлении феномена “партии власти”, имеющего сугубо российскую специфику и не наблюдаемого в странах Восточной Европы, можно видеть реализацию стратегии “эксплуататорского государства”, стремящегося сохранить свое доминирующее положение на политическом рынке [Голосов, Лихтенштейн 2001; Рябов 1998].

Политическая активность бюрократии наиболее значительна как раз в переходные для демократии периоды, когда идет быстрое формирование государственных институтов. Понятную озабоченность приверженцев неоинституционализма (например, представителя вирджинской школы П.Бернхольца) вызывает то, что чрезмерная интервенция бюрократии в политический процесс приводит к дисбалансу общественных интересов в результате искажения воли избирателей, а следовательно - к нарастанию в обществе антидемократических тенденций [Макарычев 1995]. При этом бюрократия выражает не только собственный интерес, но и интересы ряда клиентел и лоббистских групп, что еще сильнее искажает картину на политическом рынке.

Таким образом, дополнительным фактором искажения предпочтений избирателей выступают собственные запросы и “аппетиты” исполнительной власти, влияние которых ощущается не только на этапе конституирования представительных органов, но и на этапе исполнения законодательных решений. Избиратели формируют законодательные органы, эти органы комплектуют бюрократию, а та осуществляет управление избирателями. В итоге избиратели, голосовавшие за депутатов, оказываются в непосредственном подчинении у бюрократов.

\section{Институциональная эффективность и легитимность избирательных и партийных систем}

Тезис о том, что характер избирательной системы оказывает решающее воздействие на структуру межпартийной конкуренции, общепринят и вряд ли нуждается в дополнительном обосновании. Менее проработана проблема эффективности и легитимности выбора институциональных условий политической деятельности, иными словами, вопросы о том, какими именно интересами, предпочтениями, ценностями руководствуются игроки, устанавливая те или иные формальные и неформальные “правила игры”, какой 
“политический доход” они надеются получить в случае введения новых институциональных ограничений, упорядочивающих взаимодействия на политическом поле.

На нормативном уровне институционализация и легитимация политической деятельности в ходе посткоммунистических трансформаций призваны создать стабильно функционирующую, эффективную демократическую систему, т.е. обеспечить рост экономического, политического и общественного капитала. Этим задачам подчинены процедуры выбора институциональных условий политической деятельности. Однако не все участники процесса выработки новых “правил игры” имеют одинаковые “политический вес” и предпочтения. Поэтому всегда есть риск принятия согласованных, но стратегически неэффективных решений, ограничивающих доступ каких-то игроков к стратегическим ресурсам власти. В этом случае могут быть достигнуты отдельные тактические цели, но отнюдь не цель стратегическая - создание устойчивой демократической системы.

Институциональная эффективность избирательной и партийной систем в условиях демократии определяется, на наш взгляд, их способностью блокировать неудачные и поддерживать удачные коллективные действия, укрепляющие конкурентную среду и гарантирующие ротацию политических сил у власти в установленном законом порядке, без потрясений и сбоев. Априори невозможно определить, будут ли предлагаемые системы действенными или нет. Необходимо время для их проверки как на эффективность, так и на легитимность. Процесс легитимации избирательной и партийной систем есть часть общего процесса легитимации власти. Необходимость такой легитимации была заложена в самом кризисе авторитарного режима, преодоление которого и является одной из задач демократизации.

\section{Этапы легитимации избирательных и партийных систем}

В свое время нам уже приходилось писать о нормативной структуре легитимации власти, о своеобразном алгоритме такой легитимации [Ачкасов и др. 1996: 47-58]. Напомним, что данный алгоритм включает в себя:

— выработку и институционализацию избирательных правил и норм политической деятельности на основе минимального консенсуса между ведущими группами интересов;

- убежденность ключевых политических акторов в справедливости принятых правил и норм и готовность действовать в соответствии с ними; иными словами, веру в то, что указанные нормы и правила образуют эффективный демократический механизм смены правящих групп путем честной политической борьбы (плюрализм и политическая конкуренция);

— соблюдение политическими акторами принятых правил и норм.

Теперь рассмотрим с позиций неоинституционализма процесс легитимации избирательной и партийной систем. Первый и самый важный этап этого процесса — выбор и принятие правил и норм избирательной и партийной систем. Именно на данном этапе создаются условия и предпосылки достижения институциональной стабильности и эффективности указанных систем и предупреждения их попятного движения.

Неоинституционализм исходит из предположения о том, что система законов (независимо от степени их формализации) представляет собой общественный капитал, отдача от которого меняется с течением времени. Поведение политических акторов может либо укреплять этот капитал, либо уменьшать его (при отказе от соблюдения установленных законом требований); либо размывать основы политической структуры, либо поддерживать их. Все зависит от того, какая линия поведения будет казаться акторам наиболее рациональной.

С точки зрения теории игр, принятие основными политическими акторами общенациональных “правил игры” может происходить по принципам:

(a) игры “с нулевой суммой”, когда в результате взаимодействия объем материальных благ остается неизменным, но победитель (“сильный игрок”) получает все. На практике это означает, что один из участников создания “правил игры”, занимая господствующие позиции на стадии их разработки, диктует “слабым игрокам” свою волю и сознательно заставляет их принять выгодные ему нормы, дабы сохранить свое доминирование и существенно ограничить властные возможности других политических акторов; 
(б) игры с “ненулевой суммой”, когда в результате взаимодействия меняется совокупный объем благ, а выигрыш и проигрыш каждого игрока приблизительно равновероятны. Это возможно, если ни один из участников создания “правил игры” объективно не имеет доминирующего положения либо если существующие институты ограничивают — в интересах достижения более высоких, стратегических интересов (например, установления общенационального согласия) - попытки игроков воспользоваться своими временными преимуществами.

Поскольку демократия предполагает определенность процедур и неопределенность результата (в отличие от авторитарного режима с его неопределенностью процедур и определенностью результата), можно сделать следующий вывод: выбор первого варианта в условиях демократического транзита означает, по сути, продолжение прежней авторитарной традиции, носителем которой становится тот политический актор, который инициирует принятие данного варианта и настаивает на его институционализации. Результатом, скорее всего, окажется рост институциональной нестабильности в связи с обострением борьбы между основными политическими акторами. Ущемленные участники политического процесса будут стремиться внести изменения в установленные “правила игры”, скорректировать их в сторону большей справедливости, а доминирующий актор - сопротивляться такого рода изменениям и маневрировать с целью создать видимость прогресса перед лицом общественного мнения. То, что изменения рано или поздно придется принять, совершенно бесспорно, ибо большинство политических акторов, даже соглашаясь следовать существующим правилам и нормам, не будут убеждены в их справедливости и, соответственно, станут делегитимировать их своими действиями. Но если на уровне политической элиты не удается достичь консенсуса относительно правил легитимации избирательной и партийной систем, то эти системы лишаются доверия и со стороны звеньев гражданского общества и отдельных граждан. В итоге будет возрастать число избирателей, не принимающих участия в выборах или систематически голосующих “против всех”.

Таким образом, только второй вариант открывает возможность достижения институциональной стабильности и эффективности избирательной и партийной систем, поскольку строится на демократической традиции и порождает веру в справедливость и законность принятых правил и норм легитимации законодательной и исполнительной власти, а также создает необходимые институциональные условия укоренения консолидированной демократии.

\section{Противоречия между технологией создания и целями политических организаций}

Теории неоинституционализма содержат еще одну интересную формулу: “зависимость от выбранной траектории” или “зависимость от выбранного маршрута”. Эта формула первоначально была призвана объяснить то, как специфическое технологическое развитие определяло затем выбор конкретной технологии. Здесь же, вслед за Нортом, мы используем данное положение для описания одной из ключевых характеристик институционального устройства, связанной с тем, что институты формируют институциональный выбор и тем самым усложняют изменение управления политическими процессами после принятия того или иного маршрута. Дело в том, что политические партии и группы интересов - лишь следствие институционально ограниченных возможностей, которые диктуются непосредственно существующей институциональной структурой.

В постсоветской России разработка избирательного законодательства и выбор электоральной системы в 1993 г. были во многом обусловлены сложившейся в тот момент социально-политической ситуацией. Пришедшие к власти политические силы имели серьезные основания опасаться того, что они не получат необходимой поддержки на выборах, и Государственная Дума попадет под контроль КПРФ. Как писал в свое время М.Дюверже, “партии всегда развиты больше слева, чем справа, потому что там они всегда более необходимы” [Дюверже 2002: 513]. Левые в лице КПРФ несомненно превосходили тогда правых по уровню организованности, дисциплины, развития партийной инфраструктуры. Поэтому выбор смешанной модели избирательной системы был продиктован не столько стремлением власти создать условия для победы правых партий и становления стабильной и эффективной многопартийной системы, сколько желанием максимально ограничить влияние КПРФ в Госдуме. В этом плане можно констатировать, что тактическая задача волновала разработчиков электорального законодательства и создателей избирательной системы гораздо больше стратегической. Конечно, как отмечал еще Дюверже, ликвидация политических партий была бы замечательным средством парализовать левую оппозицию [Дюверже 2002: 513], но построение современной демократии невозможно без участия политических партий, без развитой многопартийности. Последующее выборы в Госдуму показали, что предложенная модель избирательной системы не позволяет решить ни одну из поставленных задач: ни обеспечить победу правых на выборах, ни создать стабильную, 
эффективную, авторитетную многопартийную систему. Вместо этого она способствовала консолидации национальной и региональной бюрократии, объединению различных ее фракций в движения и появлению все новых версий так наз. “партии власти”.

\section{Партии, институционализация партийной системы и консолидации демократии}

Как показывает мировая практика, достижение стабильной демократии и консолидации общества обеспечивают массовые и “всеохватывающие” партии, но никогда — партии “картельного типа”. Здесь уместно вспомнить об опыте стран Южной Европы, осуществивших переход к демократии в $1970-1980$-е годы_1_, а также о процессах, происходивших в Центральной Европе в конце прошлого столетия [см. Голосов 1998; Рихард, Внук-Липиньский 2002]. Рассмотрим эти процессы на примере Польши.

Начало институционализации и легитимации избирательной и партийной систем в Польше положили “круглый стол” весной 1989 г. и организованные летом того же года учредительные выборы. Основные “правила игры” были, таким образом, установлены, хотя исполнялись они еще непоследовательно. В следующие два-три года ситуация улучшилась. Реальные доказательства эффективности институционального выбора были получены уже в 1993 г., когда оппозиция взяла власть, а силы, правившие до тех пор, стали оппозицией. Это был первый сигнал о том, что ведущие политические акторы приняли новые “правила игры”, как бы те ни сказывались на них в тактическом плане. “Солидарность” уступила власть посткоммунистическим силам, признав результаты выборов справедливыми.

Вторым ключевым моментом в институционализации и легитимации системы был 1997 г., когда по результатам выборов посткоммунистические силы передали власть “Электоральной акции Солидарность” (ЭАС) и Союзу Свободы. “В это время, — пишут А.Рихард и Э.Внук-Липиньский, — не было сколько-нибудь заметной политической силы, которая бы оспорила программно демократическую процедуру легитимации режима. Такая сила не появилась потому, что для ее создания не было социальной базы. На этом основании можно сделать вывод, что примерно к 1997 г. демократическая процедура стала единственно стабильным и значимым путем легитимации режима или, используя термин Де Пальмы, популяризированный Линцем и Степаном, демократические правила стали “единственной игрой в городе” [Рихард, Внук-Липиньский 2002: 67]. Признание всеми участниками политического процесса справедливости и эффективности существующей избирательной системы привело к консолидации в Польше партийной системы. По истечению первого десятилетия посткоммунистических трансформаций не только в Польше, но и в ряде других государств Центральной Европы утвердилось “неоспоримое господство демократических процедур легитимации режима” (согласно критериям, предложенным Х.Линцем и А.Степаном) [Linz, Stepan 1996].

В случае с Россией налицо попытки легитимировать институциональную нестабильность и осуществить переход к демократии с помощью политических образований, объединяющих несколько клиентел и мало пригодных для развертывания политической деятельности в период становления демократии и гражданского общества. Большинство упомянутых образований напоминают партии картельного типа, среди которых выделяется одна, обладающая исключительными ресурсами (административными, финансовыми, информационными). Она и “назначается” (номинируется) правящей.

Смысл возникновения партий картельного типа в условиях стабильной и консолидированной демократии состоит, как известно, в том, чтобы выработать механизм распределения государственных постов между группами профессиональных политиков, основывающийся на непосредственной связи между лидерами и избирателями, сокращении дистанции между ними и предполагающий широкое использование коалиционных принципов [см., напр. Сморгунов 1999: 194]. Попытки создания аналогичных конструкций в России преследуют несколько иную цель: смонтировать механизм распределения государственных постов между группами административно-политической и экономической элиты, минимально зависящий от воли избирателей. Ни о каком сокращении дистанции между политиками и избирателями, государством и гражданским обществом в принципе не идет и речи. Но партии картельного типа не могут консолидировать демократию, поскольку они сами есть продукт ее эволюционного развития.

При неконсолидированной демократии такие партии являются дополнительным источником политической и социальной нестабильности. Они не столько интегрируют социально-экономическое и политическое пространство, сколько создают видимость интеграции; не столько способствуют росту демократической легитимности, сколько порождают тенденцию к делегитимации всего политического режима, ибо своими 
действиями формируют в обществе и внутри политического класса убеждение во временности имеющихся институтов и норм. Отсюда - линия на внесение все новых и новых поправок в избирательное законодательство от имени или по инициативе доминирующих акторов, введение дополнительных ограничений для “слабых” игроков с целью снизить риск поражения на выборах и, соответственно, уменьшения своих “политических прибылей”_2_. Тем самым доминирующие акторы повышают вероятность собственной электоральной победы, но одновременно дестабилизируют существующую институциональную систему коллективного действия по управлению и по легитимации власти.

Институционализация отношений внутри партии картельного типа (между различными группами административно-политической и экономической элиты) носит, как свидетельствует опыт России, временный характер. Различия интересов этих групп неизбежно ведут к нарушениям картельных соглашений, к борьбе между различными фракциями элиты, а также к постоянному изменению финансовых, гражданских и избирательных норм, направленному на достижение относительного преимущества одной фракции над другими.

Как известно, разрозненные “институциональные процессы могут продолжать сосуществовать друг с другом без всеохватывающей интеграции” [Бергер, Лукман 1995: 136]. Именно это мы наблюдаем сегодня в России, именно это не позволяет ее избирательной и партийной системам достичь институциональной стабильности и, следовательно, быть признанными в обществе в качестве легитимных. “Легитимация создает новые значения, служащие для интеграции тех значений, которые уже свойственны различным институциональным процессам. Функция легитимации заключается в том, чтобы сделать объективно доступными и субъективно вероятными уже институционализированные объективации” [Бергер, Лукман 1995: 151].

Все более очевидно, что принятие закона РФ “О политических партиях” — наряду с образованием федеральных округов, реорганизацией Совета Федерации, приведением регионального законодательства в соответствие с федеральным, перераспределением бюджета между федеральным центром и регионами полностью вписывается в логику административной реформы. Ее осуществление отдано в руки бюрократии, которая не заинтересована в контроле за собой со стороны каких-либо структур, разве что самого Президента и его окружения. Административно-правовой код создания большинства политических партий, выигрывавших парламентские выборы в России, не вызывает сомнений. В рамках созданного здесь политического пространства с помощью современных административных ресурсов и политтехнологий конструируются партии (или партия), ориентированные на максимизацию собственной прибыли в результате победы на очередных парламентских выборах. Говоря словами Ж.Бодрийяра, “цель не полагается в итоге, а наличествует изначально, зафиксированная в коде” [Бодрийяр 2000: 129]. Такой порядок действия делает нецелесообразным, с точки зрения бюрократии, развитие институтов гражданского общества. Подобного рода партии выражают интересы скорее государства (точнее, его бюрократического аппарата), нежели гражданского общества. Бюрократия федерального и регионального уровней, освободившись в 1991 г. от политического контроля со стороны номенклатуры КПСС, не горит желанием вновь становиться под контроль какой-либо политической организации, представляющий интересы общества и неподконтрольной ей самой. Используя терминологию Бодрийяра, можно сказать, что как правящим, так и оппозиционным политическим партиям отводится место “симулякра” политического участия.

Именно в связи с этим партии и партийная система в целом в России не легитимируются. Они отвергаются обществом по причине их искусственного происхождения. Непартийные институты гражданского общества (общественные движения, некоммерческие организации, ассоциации малого и среднего бизнеса и т.д.), осуществляющие самостоятельную, независимую от государства деятельность, не признают в большинстве политических партий равноправных партнеров, видя в них прежде всего институты, управляемые государством и нередко лишь симулирующие политическую активность. Поэтому политические партии, особенно возникшие в посткоммунистический период, не имеют прочной социальной базы и вынуждены постоянно маневрировать и мимикрировать, ища поддержки у самых различных групп населения.

\section{Пиар-компании и политические партии}

Анализируя процессы, происходящие в посткоммунистическом мире, с позиций неоинституциональной теории, нельзя обойти молчанием активность еще одного игрока на политическом поле. Речь идет о профессиональных пиар-компаниях. Они также обладают своим интересом, который не без успеха отстаивают как на институциональном, так и на внеинституциональном уровне. 
Существующие в России электоральные и партийные институты поддерживают рынок пиар-технологий, который по разным оценкам составляет около 1 млрд. долл. Слабость политических партий, их организационная и идейная рыхлость открывают перед пиар-компаниями довольно широкую перспективу. Основные политические партии (включая “партию власти”) являются для политтехнологов своеобразными “заготовками” для грядущих избирательных кампаний_3_.

Сохранение нынешнего состояния избирательных институтов и норм выгодно и этому специфическому игроку на политическом поле России. Он тоже стремится максимизировать собственную прибыль, совершенствуя электоральные технологии, заблаговременно готовясь к новым избирательным кампаниям. Для него создание системы сильных гражданских партий означало бы потерю значительной части рынка. Очевидно, что пиар-компании могут быть заинтересованы в создании и функционировании только партий картельного типа, деятельность которых предполагает активное использование политтехнологий и не требует ни развития гражданского общества, ни массового усвоения норм гражданской политической культуры, ни повышения уровня политического участия населения.

$* * *$

В заключение хотелось бы сказать, что сравнительный анализ посткоммунистических трансформаций в принципе можно осуществлять как на макро-, так и на микросоциальном уровне. Более того, чем раньше состояние переходности уйдет в историю, тем скорее будут востребованы макросоциальные подходы. Но в настоящий период эффективнее теории среднего уровня. Неоинституциональная парадигма в сочетании с транзитологией дает в руки исследователя довольно надежный инструмент сравнительного анализа трансформационных процессов, протекающих в постсоциалистическом пространстве.

Ачкасов В.А., Елисеев С.М., Ланцов С.А. 1996. Легитимация власти в постсоциалистическом российском обществе. М.

Бергер П., Лукман Т. 1995. Социальное конструирование реальности. М.

Бодрийяр Ж. 2000. Символический обмен и смерть. М.

Бойме К., фон. 1994. Теория трансформации - новая междисциплинарная отрасль знания? - Государство и право, № 7.

Васович В. 1998. Переход к демократии в посткоммунистических странах (парадоксы перехода-демократизации). - Вестник МГУ, сер. 18, № 2.

Вебер М. 1990. Основные социологические понятия. — Избранные произведения. М.

Голосов Г. 1998. Партийные системы России и стран Восточной Европы. М.

Голосов Г.В., Лихтенштейн А.В. 2001. “Партии власти” и российский институциональный дизайн: теоретический анализ - Полис, № 1.

Дюверже М. 2000. Политические партии. М.

Дюркгейм Э. 1991. О разделении общественного труда. Метод социологии. М.

Закатова А. 2002. Партийная система еще не работает. Если КПРФ и “Единой России” нужно будущее, им нужно измениться. - Независимая газета, 17.04.

Ильин М.В. 1997. Слова и смыслы: опыт описания ключевых политических понятий. М.

Ильин М.В., Сморгунов Л.В. 2001. Сравнительная политология. - Политическая наука, № 2.

Капустин Б. 2001. Конец “транзитологии”? (О теоретическом осмыслении первого посткоммунистического десятилетия). — Полис № 4.

Макарычев А.С. 1995 Принципы и параметры общественного выбора (исследования вирджинской школы). 
— Полис, № 4.

Норт Д. 1997. Институты, институциональные изменения и функционирование экономики. М.

О’ Доннел Г. 1994. Делегативная демократия. - Пределы власти, № 2-3.

Патрушев С.В. 2001. Институционализм в политической науке: Этапы, течения, идеи, проблемы. Политическая наука, № 2.

Растоу Д. 1996. Переходы к демократии: попытка динамической модели. — Полис, № 5.

Рихард А., Внук-Липиньский Э. 2002. Источники политической стабильности и нестабильности в Польше. - Социологические исследования, № 6.

Рябов, А. 1998. “Партия власти” в политической системе современной России. — Макфол М., Марков С., Рябов А. (ред.). Формирование партийно-политической системы в России. М.

Сморгунов Л.В. 1999. Сравнительная политология. Теория и методология измерения демократии. СПб.

Штомпка П. 1996. Социология социальных изменений. М.

Linz J.J., Stepan A. 1996. Problems of Democratic Transition and Consolidation. Southern Europe, South America, and Post-Communist Europe. Baltimore, L.

Schmitter Ph. C., Karl T.L. 1994. The Conceptual Travels of Transitologists and Consolidologists: How Far to the East Should They Attempt to Go? — Slavic Review, vol. 53, № 1.

1 В Греции созданное А.Папандреу еще в 1974 г. социалистическое движение ПАСОК сумело не только осуществить переход к демократии, но и сохранить власть в своих руках вплоть до настоящего времени. (Правда, в 1989 - 1993 гг. правительство формировала правоцентристская “Новая демократия”.) В Испании в ноябре 1975 г., после смерти Франко и воцарения Хуана Карлоса были легализованы ряд политических партий и профсоюзы. В декабре 1978 г. вступила в силу новая конституция, а спустя четыре года, в 1982 г., к власти пришло правительство, сформированное Испанской социалистической рабочей партией, под руководством которой, собственно говоря, и были сделаны основные шаги по созданию демократической политической системы.

2 В этот контекст прекрасно вписывается недавняя инициатива центристов, предложивших поднять избирательный порог для партий, претендующих на место в Государственной Думе.

3_ Как выразился глава “Фонда эффективной политики” Г.Павловский, “между выборами наши партии представляют собой сырье для будущих избирательных проектов”. То есть партии суть “полуфабрикаты”, а выборы - “конкурсы искусств электоральных проектов” [цит. по Закатова 2002]. 